\title{
Konserwatyzm wobec nurtu ponowoczesności - wzajemne relacje i zależności
}

DOI 10.35757/CIV.2014.16.08

Każdy król ma swego błazna, dlaczego filozofia nie miałaby skorzystać $z$ tej szansy i dzięki postmodernistycznej błazenadzie raz jeszcze stać się królewska? Wolfgang Welsch

Konserwatyzm a postmodernizm - zestawienie to jest chyba intelektualnym wyzwaniem. Na pierwszy rzut oka oba nurty światopoglądowe dzieli przepaść nie do przebycia. Autorzy konserwatywni bądź reprezentujący światopogląd chrześcijański postmodernistów odsadzaja od czci i wiary. Zarzuca im się relatywizm poznawczy, irracjonalizm, subiektywizm, antyhumanizm, sprowadzający człowieka do języka i nihilizm kulturowy. „Trzeba na tym miejscu jasno powiedzieć - pisze ks. Krzysztof Gódź - że postmodernizm rujnuje - jak nic i nikt dotąd - całą myśl chrześcijańską: filozofię i teologię. Tak groźnego wroga jeszcze nie było w historii, który podważa wszelkie podstawy, zagrażajacc całej kulturze ludzkiej”' . Bronisław Wildstein w artykule opublikowanym w „Do Rzeczy” stwierdza

Michat Graban - doktor nauk politycznych, specjalizuje się w problematyce ponowoczesności, globalizacji i tożsamości lokalnej Gdyni. Pracuje w Urzędzie Marszałkowskim w Gdańsku.

1 Ks. K. Góźdź: Problem teologii ponowoczesności, w: ks. K. Góźdź, ks. J. Chyła, ks. S. Kunka (red.): Teologia wobec nurtu ponowoczesności, Wydawnictwo Bernardinum, Pelplin 2012, s. 7. 
z kolei: „[...] postmodernizm, który deklarował się jako rozliczenie błędów modernizmu, był jego konsekwentna kontynuacja [...] Ponowoczesne wyznanie wiary zakłada więc, że lekarstwem na totalitaryzm ma być to, co legło u jego podłoża, czyli burzenie tradycyjnego ładu, tyle tylko, że jeszcze bardziej zintensyfikowane"2.

Wydaje się jednak, że w tych twierdzeniach jest wiele nieporozumień. Ludzie skłonni sa postrzegać nurt ponowoczesności jako groźny przykład myślenia ideologicznego, z którym autorzy ponowocześni nie chcą mieć przecież nic wspólnego. Jak twierdzi Gianni Vattimo, ponowoczesność nie może być identyfikowana „z jakąś głębia o charakterze teologiczno-negatywnym"3. Jeżeli do problemu podejdziemy zatem bez ideologicznych uprzedzeń, okaże się, że oba punkty widzenia, mimo iż wyrastaja $z$ diametralnie odmiennych źródeł, maja wiele punktów stycznych. Analizie zbieżności i rozbieżności konserwatyzmu $z$ ponowoczesnościa poświęcony będzie niniejszy artykuł.

\section{Kwestie terminologiczne}

Terminy „ponowoczesność” i „konserwatyzm” należą do wieloznacznych. Często zwraca się uwage zwłaszcza na niejasny charakter terminu „ponowoczesność". Owa nieostrość skłania wielu badaczy do formułowania tezy o jego bezużyteczności. Osobiście $z$ teza tą się nie zgadzam. Wieloznaczność terminu „ponowoczesność" zwiazana jest $z$ faktem, iż wyraża on klasę zjawisk o charakterze wewnętrznie złożonym, eklektycznym i pluralnym. Pojawiaja się także tendencje zmierzające do ukonkretnienia tego terminu bądź jego unaukowienia. Uważam jednak, że jest on wystarczająco pojemny, aby stać się skutecznym narzędziem opisu, adekwatnym do uchwycenia wyjątkowo złożonej natury naszych czasów.

2 B. Wildstein: Nowy totalitaryzm, „Do Rzeczy”, 3-9 listopada 2014, nr 45/093, s. 58.

3 G. Vattimo: Koniec nowoczesności, przekład M. Surma-Gawłowska, Universitas, Towarzystwo Autorów i Wydawców Prac Naukowych Universitas, Kraków 2006, s. 25. 
Inna sprawa jest pokazanie różnicy między terminami „postmodernizm” a „ponowoczesność”. Choć w literaturze przedmiotu często stosuje się je zamiennie, w rzeczywistości ich zakresy znaczeniowe się nie pokrywają. „Postmodernizm” jest kolejnym -izmem (po modernizmie, konserwatyzmie etc.) i jako taki może uwypuklać zaangażowanie ideologiczne używającego go badacza. „Ponowoczesność” $z$ kolei raczej wyraża obraz tendencji społeczno-kulturowych naszego świata bądź całą epokę ponowoczesności, jak określa ja Jean-François Lyotard. Termin ten jest wolny od wartościowania ideologicznego. W opracowaniu będę się posługiwał drugim z wymienionych znaczeń. Ponowoczesność będę wyrażał w kategoriach pesymistycznych, odwołujac się zatem do tych badaczy, którzy używaja określeń o charakterze katastroficznym i apokaliptycznym do wyrażenia istotnych atrybutów otaczającego nas świata. Przywołanie takich akcentów w pewnym sensie leży w naturze terminu „ponowoczesność”. O ile bowiem „postmodernizm" w znaczeniu pewnej ideologii musi wyrażać afirmatywny stosunek badacza, o tyle przez „ponowoczesność” rozumiemy obszar tendencji społecznych, które można charakteryzować, posługując się określeniami o znaczeniu pesymistycznym.

Jeżeli chodzi o termin „konserwatyzm”, to używam go głównie w celu określenia jego francuskiej odmiany, zwanej reakcjonizmem (bądź tradycjonalizmem). Wyraża ona zaangażowanie antagonistów wielkiej rewolucji francuskiej. Przyjmuję bowiem za Adamem Wielomskim, że odmiana ta $\mathrm{w}$ najpełniejszym stopniu oddaje istotę doktryny konserwatywnej ${ }^{4}$. Aby jednak opowiedzieć się za konserwatyzmem, niezbędny jest, według mnie, pewien dystans do samego siebie ${ }^{5}$, podobny do tego, który prezentowali polscy konserwatyści okresu zaborów - Stańczycy, noszący wdzięczne imię

\footnotetext{
${ }_{4}$ A. Wielomski: Konserwatyzm. Główne idee, nurty, postacie, Fijorr Publishing, Warszawa 2007, s. 77-86.

5 Przykładem takiej analizy myśli konserwatywnej, która ma dystans do samej siebie i została sporzadzona w duchu autoironii, jest słynny esej Emila Ciorana: Joseph de Maistre. Esej o myśli reakcyjnej, w: idem: Ćwiczenia z zachwytu. Eseje i portrety, „Czytelnik”, Warszawa 1998 , s. 5-52.
} 
królewskiego błazna. Ta szczypta autoironii pozwoli mi odnaleźć więcej punktów stycznych między nurtem ponowoczesności a konserwatyzmem.

\section{Stosunek do rozumu instrumentalnego i oświeceniowej idei postępu}

Zarówno konserwatyzm, jak i nurt ponowoczesności cechują się sceptycznym stosunkiem względem oświeceniowego projektu nowoczesności. Mając za punkt wyjścia wspólną krytykę tego projektu, niektórzy autorzy analizuja konserwatyzm przez pryzmat ponowoczesności. Należy do nich Andrzej Gniazdowski, który w swojej książce o Josephie de Maistrze kieruje się chęcia odnalezienia „kontrrewolucyjnych korzeni niektórych wątków współczesnej hermeneutyki”. Jak stwierdza wspomniany autor: „[...] filozoficzny sens tradycjonalistycznej krytyki filozofii stanowi właśnie owo dążenie do przezwyciężenia nowożytnego paradygmatu myślenia, istotnego przeformułowania jego podstawowych kategorii: pojęcia teorii, rozumu, podmiotowości. Myśl de Maistre'a będzie tu zatem traktowana jako jedna $z$ pierwszych prób odniesienia się do zjawiska, które współcześnie przyjęło się określać mianem kryzysu racjonalizmu [podkr. - A.G.]"?.

Ów kryzys racjonalizmu znajduje swoje kompetentne ujście nie tylko u pisarzy konserwatywnych, ale i u utożsamianych z kultura ponowoczesna. Zacznijmy od konserwatyzmu. Zgodnie $z$ wykładnia Wielomskiego francuska myśl konserwatywna krytykuje utopizm projektu oświeceniowego. Utopizm ten kieruje się chęcią budowy świata zaprojektowanego przez człowieka i jego wyemancypowany umysł, który poczynając od XVIII wieku, stawał się dominujaccy w filozofii. Wtedy to człowiek zbuntował się przeciw Bogu i ni-

6 A. Gniazdowski: Filozofia i gilotyna. Tradycjonalizm Josepha de Maistre'a jako hermeneutyka polityczna, Wydawnictwo Instytutu Filozofii i Socjologii PAN, Warszawa 1996, s. 61.

7 Ibidem, s. 10. 
czym demiurg dumnie rozpoczą dzieło samozbawienia ${ }^{8}$. Wielomski odtwarza tu komponenty myśli niemieckiego historyka idei Erica Voegelina, który w typowy dla siebie sposób charakteryzuje zjawisko immanentyzacji rozumu, polegające na zerwaniu $z$ rozumem transcendentnym, charakterystycznym dla filozofii klasycznej. Jednocześnie, według Voegelina, immanentny, wewnątrzświatowy sens dziejów jest opowiadany w epoce oświecenia w języku chrześcijańskiej historii świętej, np. przez podobną symbolikę (trynitaryzm) czy odwołania ${ }^{9}$. Dlatego owa immanentyzacja zyskuje u niemieckiego historyka idei miano gnozy.

Dla angielskich konserwatystów Dawida Hume'a i Edmunda Burke'a rozum ludzki musi być wsparty autorytetem tradycji, Kościoła i innych instytucji. Mądrość teoretyczną należy odróżnić od praktycznej. Ta druga, $z$ która identyfikuje się Burke, winna być zahartowana przez upływ czasu ${ }^{10}$. Wedle Burke'a to, co oświeceniowcy nazywali przesądami, jest - zwykle - zbiorowa mądrością wspólnoty. Burke broni utrwalonego oraz sprawdzonego przez pokolenia modelu życia, uznając jednakże potrzebę jego zmian i adaptacji do nowych warunków. Jeszcze radykalniejsze stanowisko względem racjonalizmu prezentowali ci $z$ konserwatystów, którzy konstatowali sprzeczność między rozumem a wiara, a należeli do nich np. Henryk Rzewuski czy Juan Donoso Cortez ${ }^{11}$.

\footnotetext{
$8 \mathrm{~W}$ celu zobrazowania tego utopizmu Adam Wielomski wprowadza rozróżnienie na rzeczywistość prawdziwą i rzeczywistość nieprawdziwą. Tę pierwsza wyraża za pomoca kategorii idei $z$ filozofii platońskiej. Zgodnie $z$ nia rzeczywistość prawdziwa jest idealna, to rzeczywistość, która możemy ujrzeć dopiero wtedy, gdy wyjdziemy na zewnątrz z Platońskiej jaskini i odtrącimy świat cieni jako iluzji. W praktyce będzie to oznaczało powrót do świata ładu, autorytetu, dyscypliny i władzy monarszej sprzed rewolucji francuskiej. Rzeczywistość nieprawdziwa $z$ kolei to świat zaprojektowany przez oświeceniowych filozofów i ich wyemancypowane umysły. Por. A. Wielomski: Prawica $w X X$ wieku, Wydawnictwo von borowiecky - Uniwersytet Przyrodniczo-Humanistyczny, Radzymin - Siedlce 2013, s. 22.

9 E. Voegelin: Od oświecenia do rewolucji, przekład Ł. Pawłowski, Wydawnictwa Uniwersytetu Warszawskiego, Warszawa 2011.

${ }^{10}$ E. Burke: Rozważania o rewolucji we Francji $i$ o debatach pewnych towarzystw londynskich zwiazanych $z$ tym wydarzeniem, wyrażone $w$ liście, który miał zostać wysłany do pewnego gentlemana w Paryżu, przekład D. Lachowska, Wydawnictwo „Znak” - Fundacja im. Stefana Batorego, Kraków - Warszawa 1994, s. 78.

${ }^{11}$ A. Wielomski: Od grzechu do apokatastasis. Historiozofia Josepha de Maistre'a, Fijor Publishing, Warszawa 2011, s. 180.
} 
Radykalny w krytyce rozumu jest przywoływany na poczatku doktor kontrrewolucji - Joseph de Maistre. Francuski tradycjonalista $z$ dużą zawziętością tropi wszelkie przejawy buntu rozumu w jego epoce, oskarża go o "pychę" i "ducha dzikiej metafizyki”" De Maistre wina za wybuch rewolucji obarcza przesiakniętych wolnomyślicielstwem filozofów, zasadę powszechnego nauczania i zasadę samodzielnego, niezapośredniczonego przez autorytety docierania do prawdy. „Nie ma nic gorszego niźli nagłe oświecenie ignorantów"13 - pisze Wielomski, relacjonując poglądy de Maistre'a.

Myśl konserwatywna dystansuje się od prometejskiego optymi$z \mathrm{mu}$, będącego emanacją wiary $\mathrm{w}$ postęp. Dlatego konserwatyści tropia wszelkie przejawy myślenia konstruktywistycznego, które manifestowały się utopijna wiara, że wraz $z$ postępem dziejowym uda się rozwiazać ludzkie bolączki i uczynić świat lepszym dla człowieka. Zwalczali politykę planowa, zalaż̇ki kreacjonizmu i „inżynierii społecznej”, która miała być realizowana za pomoca nowożytnej nauki ${ }^{14}$. W stosunku do idei czasu konserwatyści przeciwstawiali się oświeceniowej koncepcji, zgodnie $z$ którą historia rozumiana jako upływ czasu jest podporządkowana człowiekowi. Uważali, iż czas jest domena Boga, natury, losu bądź innych przewyższających ludzkie zdolności percepcyjne okoliczności. Zgodnie $z$ tym rozumowaniem de Maistre uprawia swego rodzaju teodyceę, uznając Opatrzność za podmiot dziejów. Ideę postępu tym samym uważa za przejaw „nieuprawnionej sekularyzacji idei Opatrzności, efekt uzurpacyjnego charakteru emancypacyjnych dążeń człowieka”"15.

W pewnym sensie stanowisko myśli ponowoczesnej jest podobne do konserwatywnej: ona również krytykuje epokę oświecenia wraz $z$ jej racjonalizmem i wiara $w$ postęp. $Z$ tego też powodu autorom ponowoczesnym przypina się niekiedy łatkę konserwatystów. Czynił tak m.in. Jürgen Habermas, krytykując w ten sposób irracjo-

\footnotetext{
${ }^{12}$ A. Gniazdowski: Filozofia i gilotyna..., s. 67.

${ }^{13}$ A. Wielomski: Od grzechu do apokatastasis..., s. 186.

${ }^{14}$ Ibidem, s. 185.

${ }^{15}$ A. Gniazdowski: Filozofia i gilotyna..., s. 169-170.
} 
nalizm Jeana-François Lyotarda. Habermas tym samym zarzuca francuskiemu myślicielowi zdradę lewicowych ideałów, $z$ którymi ten był związany $\mathrm{w}$ młodości.

W tym kontekście nie od rzeczy tu będzie wskazanie na lewicowe ideały, gdyż autorami silnie utożsamianymi ze współczesnym, tj. ponowoczesnym, irracjonalizmem sa właśnie przedstawiciele nowej lewicy, czyli szkoły frankfurckiej: Max Horkheimer i Theodor W. Adorno. Wielu myślicieli ponowoczesnych odwołuje się do ich argumentacji zawartej w klasycznym już dziele Dialektyka oświecenia z 1947 roku. Autorzy zajmuja się w nim fenomenem ludzkiego rozumu, a zwłaszcza jego na wskroś praktyczną natura, sprawiająca, że myślenie jest bezpośrednio działaniem, tj. pewnym projektem sensu i zarazem programem jego samoczynnej realizacji. Jak twierdza (a zawarte jest tu podobieństwo do myśli konserwatywnej): „Porządkujący umysł równy jest stwórczemu bogu, gdyż tak samo sprawują władzę nad naturą. Jeśli człowiek jest istota na obraz i podobieństwo boże, to zasada tego podobieństwa jest suwerenne panowanie nad tym, co istnieje, władcze spojrzenie, zwierzchność"16. Tak definiowany rozum instrumentalny swojej siły nie czerpie już z żadnego transcendentnego „zewnątrz”, lecz wyłącznie ze własnej immanencji. Konsekwencje takiego działania rozumu charakteryzują się bezwzględną logika, np.: okrucieństwo II wojny światowej, ideologia nazistowska czy komunistyczna i ich następstwa, jak Holocaust czy Auschwitz.

Zarówno myśl nowolewicowa, jak i ponowoczesna krytykuja zatem totalitarne roszczenia oświeceniowego rozumu. Warto teraz odpowiedzieć na pytanie: Co zamiast niego zamierzają wprowadzić? I tak Habermas (który uważa się za modernistę) stoi na stanowisku rozumności właściwej dla dyskursu komunikacyjnego. Myśliciele ponowocześni sa jednak bardziej zdecydowani w zapędzie zrywania ze spuścizna oświecenia. O ile rozum oświecony był, wedle nich, zdolny do tworzenia w perspektywie uniwersalnej do „wielkiej nar-

${ }^{16}$ M. Horkheimer, T.W. Adorno: Dialektyka oświecenia. Fragmenty filozoficzne, przekład M. Łukasiewicz, Wydawnictwo Krytyki Politycznej, Warszawa 2010, s. 20-21. 
racji”, o tyle rozum ponowoczesny jest zjawiskiem pluralnym i jako konsekwencja Lyotardowskiej „poróżnionej natury języka” może jedynie wzbić się na poziom „małej narracji”17. Wolfang Welsch wprowadza do tego jeszcze ideę rozumu „transwersalnego”, która dostrzega $\mathrm{w}$ rozumie zdolność do przekraczania granic poszczególnych typów racjonalności i przeskakiwania między nimi niczym „Z wyspy na wyspę”. Ta zdolność do przechodzenia rozumu nie ma jednak prowadzić do jego totalizacji. Koncepcję „pluralnego rozumu” sytuuje się jako występująca „pomiędzy modernizmem a postmodernizmem” i określa ja jako „korektę modernizmu” ${ }^{18}$.

Podobnie jak do rozumu myśliciele ponowocześni sceptycznie podchodzą także do idei postępu. Wiara w postęp jest samym sednem ideologii oświeceniowej, przyjmującej, że przejście od wcześniejszych do późniejszych czasów zwykle wiązać się miało ze zmiana na lepsze. Nurt ponowoczesności stara się tę tezę przezwyciężyć, choć nie zawsze mu się to udaje. Myśliciele ponowocześni napotykają bowiem na pewne trudności, gdy chca wyrazić przeobrażenie od nowoczesności do ponowoczesności. Ponowoczesność wszak, chcąc wyrazić własna odmienność od nowoczesności, musi używać tych samych terminów, którymi posługiwano się w celu wyrażenia przejścia od porządku tradycyjnego do nowoczesnego. Terminów, które odwołuja się do „przezwyciężenia czasowego”, tak jakby ponowoczesność była kolejnym moderne. Jest to błędne. Ponowoczesność musi bowiem oznaczać wyjście poza ramy historyzmu. Jak dowodzi Gianni Vattimo: „[...] przezwyciężenie jest kategoria typowo nowoczesna i dlatego właśnie całkowicie nieprzydatna do tego, żeby być podstawą wyjścia $z$ nowoczesności. [...] Praw-

\footnotetext{
17 J.-F. Lyotard: Kondycja ponowoczesna. Raport o stanie wiedzy, przekład M. Kowalska, J. Migasiński, Fundacja „Aletheia”, Warszawa 1997, s. 57-66; 111-119. Idem: Poróżnienie, przekład B. Banasiak. Wydawnictwo Uniwersytetu Jagiellońskiego, Kraków 2010, s. 7-39. Jak pisze Wolfgang Welsch: „Rozum - przynajmniej jako racjonalność - okazuje się coraz bardziej spluralizowany, podzielony, wręcz zatomizowany. Rozdwojenie wyznacza próg: nie ma już drogi odwrotu do jedności, lub też można ja sobie wyobrazić jedynie za pomoca rozdwojenia, wielości, różnicy”. Idem: Nasza postmodernistyczna moderna, przekład R. Kubicki, A. Zeidler-Janiszewska, Oficyna Naukowa, Warszawa 1998, s. 361-362.

${ }^{18}$ W. Welsch: Nasza postmodernistyczna moderna..., s. 405-440.
} 
dopodobnie w tym też leży racja, dla której Nietzsche w drugim Niewczesnym rozważaniu nie może już pomyśleć wyjścia $z$ nowoczesności jako rezultatu przezwyciężenia krytycznego, lecz sięga do mitu i do sztuki"19.

Ponowoczesność przezwycięża także myślenie ideologiczne. Ideę wyzbycia się ideologicznych uzasadnień, majacych na celu wyrażenie przejścia od nowoczesności do ponowoczesności prezentuje Baumanowska koncepcja „ponowoczesności jako nowoczesności bez iluzji" ${ }^{20}$. Zgodnie $z$ ta koncepcja ponowoczesność nie żywi już wiary w jakieś źródło ładu, które miało być konsekwencją postępu, i wie, że moralna niepewność, nierozstrzygalność i ambiwalencja jest stanem trwałym, w którym musimy się uczyć żyć. „Płynna nowoczesność - pisze w innej pracy Bauman - odebrała przyszłości kredyt zaufania. Miara upływu czasu nie jest już dziś przejście od gorszego do lepszego, ale przemijanie, umykanie szans na poprawę"21.

Przywodzi tu na myśl „przeciwstawienie modernej postawy twórcy-demiurga porządkującego świat postawie pozbawionego złudzeń postmodernego autora dryfującego wśród chaosu"22. Obserwując otaczający nas świat, natrafiamy na wiele symptomów kryzysu idei postępu. Zwraca się uwagę, że mimo coraz większej prędkości zmian nie pojawia się nic nowego, ponieważ to, co nowe, nie dysponuje takim czasem, który wystarczyłby do tego, aby stało się ono czymś niepowtarzalnym, nieodwracalnym, trwałym. Totalna

\footnotetext{
${ }_{19}$ G. Vattimo: Nihilizm i postmodernizm $w$ filozofii, przekład M. Potępa, w: S. Czerniak, A. Szahaj (red.): Postmodernizm a filozofia. Wybór tekstów, Wydawnictwo Instytutu Filozofii i Socjologii PAN, Warszawa 1996, s. 185-186.

20 Jak pisze Bauman: „Iluzje te sprowadzają się do przekonania, że nieład ludzkiego świata jest stanem przejściowym zaledwie i odwracalnym, który wcześniej czy później zastapia uporządkowane i systematyczne rządy rozumu". Zob. idem: Etyka ponowoczesna, przekład J. Bauman, J. Tokarska-Bakir, Fundacja „Aletheia”, Warszawa 2011, s. 50. „Jeszcze jeden wysiłek, jeszcze jedna zwycięska bitwa rozumu - pisze Bauman - i harmonia stanie się faktem, i to raz na zawsze, nieodwracalnie". Ibidem, s. 15.

${ }^{21}$ Z. Bauman: Utopia bez toposu, w: M. Jacyno, A. Jawłowska, M. Kempny (red.): Kultura $w$ czasach globalizacji, Wydawnictwo Instytutu Filozofii i Socjologii Polskiej Akademii Nauk, Warszawa 2004, s. 30.

${ }^{22}$ B. Baran: Postmodernizm, Wydawnictwo Inter Esse, Kraków 1992, s. 200.
} 
modernizacja wikła się w mityczny krąg powtarzalności tego samego, Nietzscheańskiego „wiecznego powrotu”, przed czym chciała uciec nowoczesność, opowiadając się jednocześnie za linearnym modelem czasu $^{23}$. Ponowoczesność kwestionuje tę linearność. Michel Foucault charakteryzuje zjawisko nieciagłości dyskursu. Cechuja go historyczne przerwy w rozumieniu, zmiany w sposobie konceptualizacji i postrzegania rzeczy. Jego „archeologia mówi o cięciach, uskokach, przerwach, o zupełnie nowych formach pozytywności czy nagle przekształconych układach" ${ }^{24}$.

Zwróćmy uwage na jeszcze jedną konsekwencję diagnozy o końcu myślenia ideologicznego. Często zwraca się uwagę, że ponowoczesność nie jest wymysłem filozofów, lecz stanowi realność świata naszego życia ${ }^{25}$. Podobnie jak w sztuce, także w filozofii zaciera się różnica między twórca a odbiorca. Dzieje tak dlatego, iż w okresie śmierci ideologii oraz końca epoki postępu możemy sobie wyobrazić taka odmianę ponowoczesności, która nie afirmuje (za pośrednictwem narratora) jakiegoś zespołu charakterystycznych dla siebie poglądów na świat, jak czynił to modernizm. Patrząc $z$ tego punktu widzenia, widzimy, że ponowoczesność to raczej odbicie, ślad, fotografia status quo - czyli towarzyszącej nam rzeczywistości społeczno-kulturowej, w której różni ludzie i różne środowiska kierują się swoimi „małymi narracjami”. Pokazuje nam ona tendencje dominujące w społeczeństwie, polityce, kulturze, religii itp., ich wzajemne uwikłania, aporie, antynomie i wewnętrzna złożoność. Tę pozbawioną właściwości i celowości rzeczywistość społeczna Jean Baudrillard określa mianem „masy”26.

Porównując zatem stosunek do rozumu instrumentalnego myśli konserwatywnej i myśli ponowoczesnej, należy podkreślić, że

\footnotetext{
${ }^{23}$ Ks. I. Bokwa: Nowoczesność i ponowoczesność - wprowadzenie do problematyki, w: ks. K. Góźdź, ks. J. Chyła, ks. S. Kunka (red.): Teologia wobec nurtu ponowoczesności..., s. 66 .

${ }^{24}$ M. Foucault: Archeologia wiedzy, przekład i opracowanie A. Siemek, De Agostini - Ediciones Altaya Polska, Warszawa 2002, s. 198.

${ }^{25}$ W. Welsch: Nasza postmodernistyczna moderna..., s. 7-8.

${ }^{26}$ J. Baudrillard: W cieniu milczacej większości albo Kres sfery społecznej, przekład S. Królak, Wydawnictwo Sic!, Warszawa 2006, s. 5-23.
} 
w warstwie krytycznej stosunki obu myśli sa podobne. Oba poglądy krytykuja praktyczność i immanentyzm oświeconego rozumu, który ma inklinacje demiurgiczne. Oba też uwypuklaja dramatyczne konsekwencje oświeconego rozumu. Postmodernistyczny strach przed Holocaustem znajduje tu swoja prefigurację w konserwatywnej krytyce rewolucyjnego terroru, który był pierwszą odsłona nowożytnego totalitaryzmu. W inny sposób postrzegana jest jednak alternatywa dla rozumu instrumentalnego. O ile konserwatyści dostrzegaja ją w formie wycofania się rozumu do poziomu transcendencji, która stanowi najlepsza zaporę przed grzechem wolnomyślicielstwa, o tyle myśliciele ponowocześni uważają, iż to właśnie transcendentna „metafizyka obecności” jest odpowiedzialna za wszystkie wypaczenia oświeceniowego rozumu, jego zaciętość i radykalizm. Zgodnie $z$ tym ostatnim stanowiskiem nowoczesność nie znajduje się na antypodach porzadku tradycyjnego (jak to widzą konserwatyści), lecz jest rezultatem metafizyki i moralności platońsko-chrześcijańskiej27. Jeżeli zaś chodzi o stosunek do idei postępu, to myś1 konserwatywna i ponowoczesna są zbliżone. Obie przezwyciężają linearna koncepcję czasu na rzecz czegoś, co wykazuje podobieństwa do cyklicznej koncepcji czasu, Nietzscheańskiego „wiecznego powrotu” bądź „ucieczki w mit i sztukę”, w każdym razie nie ma tu przeświadczenia, że wraz $z$ postępem dziejowym można zmieniać świat na lepsze. Raczej musimy uczyć się żyć w warunkach rosnącej niepewności, nierozstrzygalności i ambiwalencji.

\section{Pesymizm naszych czasów i tęsknota za przeszłościa}

$\mathrm{W}$ poprzednim punkcie zwracano uwagę na rezygnację $z$ zacięcia ideologicznego autorów ponowoczesnych, co jawi się jako konsekwencja „decentracji podmiotu”. Ponowoczesność więc należy traktować nie jako kolejna ideologię, lecz jako obraz tendencji

${ }^{27}$ G. Vattimo: Koniec nowoczesności..., s. 160. 
myślowych dominujacych w globalnym świecie. Trzeba jednak zadać pytanie o ocenę tego obrazu: Czy zawiera ona akcenty optymistyczne czy pesymistyczne? Będę się starał ukazać podobieństwa myśli konserwatywnej do ponowoczesnej, dotyczace ich generalnie pesymistycznej, nierzadko wręcz apokaliptycznej natury w ocenie współczesnego, ponowoczesnego świata.

Pesymizm myśli konserwatywnej ma swoje źródła w ocenie skutków rewolucyjnej katastrofy. Pesymizm ten zawarty jest w myśli Edmunda Burke'a, a przede wszystkim w poglądach francuskich doktorów kontrrewolucji. Jak twierdzi de Maistre: „Tylko gwałt jest we wszechświecie; my jednak jesteśmy zepsuci przez nowoczesna filozofię, która mówi, że wszystko jest dobrze, podczas gdy wszystko zostało skażone przez zło i w pewnym sensie wszystko jest źle, ponieważ nic nie znajduje się na swoim miejscu”28. Według de Maistre'a rewolucja jest „czysta nieczystościa”, jest „szatańska w swej istocie"29, doświadczenie apokaliptyczne zaś przejawia konfrontację $z$ wizja totalnej zagłady, w której granice rewolucji okazuja się granicami świata ${ }^{30}$. Rewolucja, podobnie jak wojna, sa postrzegane przez de Maistre'a w kategoriach religijnych, widzi on w nich „konieczność” i „karę za grzechy”31. U źródeł tej postawy znajdowało się tradycyjne chrześcijańskie przekonanie, iż w następstwie grzechu pierworodnego ludzie ulegli deprawacji. Moga jednak powrócić do Boga dzięki apokatastazie, czyli powrotowi wszystkich bytów do prajedności z Bytem Najwyższym, wyznawca tego poglądu był de Maistre ${ }^{32}$.

Także inni francuscy kontrrewolucjoniści, tacy jak Franck Ferrand, Jacques Mallet du Pan, Antoine de Rivarol, François Dominique de Regnaud de Montlosier, podkreślaja wyjatkowy charakter francuskiej rewolucji, co oznacza, że „należy się wystrzegać porów-

\footnotetext{
${ }^{28}$ Cyt za: J. Szacki: Kontrrewolucyjne paradoksy. Wizje świata francuskich antagonistów Wielkiej Rewolucji 1789-1815, Państwowe Wydawnictwo Naukowe, Warszawa 1965, s. 112.

${ }^{29}$ Ibidem, s. 38.

${ }^{30}$ A. Gniazdowski: Filozofia i gilotyna..., s. 182.

${ }^{31}$ Ibidem, s. 65.

${ }^{32}$ A. Wielomski: Od grzechu do apokatastasis..., s. 335.
} 
nywania tej rewolucji $z$ jakakolwiek inna rewolucja [...]”, bowiem „zniszczyła ona nie tylko społeczeństwo, ale najpierwsze podstawy wszelkiego społeczeństwa"33.

Także w kolejnych fazach okresu nowożytnego konserwatyści nie mieli powodów do optymizmu. Zgodnie $z$ ich logika świat nie stawał się lepszy, lecz na odwrót: coraz bardziej pogrą̇ał się w mroku. Przejawiało to się w kolejnych fazach procesów demokratyzacji życia społecznego, emancypacji jednostkowej i sekularyzacji. W rezultacie myśl konserwatywna, choć nie tak radykalnie, jak czynili to kontrrewolucjoniści, ubolewała i wciąż ubolewa nad kryzysem tradycyjnych wartości, patriotyzmu, erozją systemu ról społecznych, brakiem zaufania do oficjalnych instytucji. Istotna figura krytyki staje się osamotniony żywot zagubionej i zamkniętej $\mathrm{w}$ sobie jednostki w zatomizowanym świecie. Zgodnie $z$ tym rozumowaniem społeczeństwo staje się bezkształtna masą. Konserwatyści identyfikowali się także $z$ niektórymi diagnozami Fryderyka Nietzschego (nowoczesność jako zjawisko dekadencji) oraz $z$ koncepcja Zmierzchu Zachodu Oswalda Spenglera.

Niektórzy współcześni konserwatyści z pesymizmu czynią swoją wizytówkę. I tak Roger Scruton w książce Pożytki z pesymizmu i niebezpieczeństwa fałszywej nadziei pokazuje, że tragedie i katastrofy europejskiej historii były skutkami bezpodstawnego optymizmu i wypływających $z$ niego fałszywych stereotypów myślowych ${ }^{34}$.

Jeżeli chodzi o pesymizm ponowoczesności, warto rozpocząć od konkluzji, że nie jest on reprezentatywny dla całej tej formacji. Wielu $z$ myślicieli ponowoczesnych wyraża bezkrytyczna aprobatę dokonujacych się przeobrażeń, aby wymienić choćby „bezchmurna radość” $z$ nadejścia postmodernizmu Richarda Rorty'ego bądź „pochmurna”, ale jednak radość, takich filozofów jak Lyotard, Welsch czy Derrida. Niemniej jednak faktem jest, że istnieje także pogłębio-

\footnotetext{
${ }^{33}$ J. Szacki: Kontrrewolucyjne paradoksy..., s. 37.

${ }^{34}$ R. Scruton: Pożytki z pesymizmu i niebezpieczeństwa fałszywej nadziei, przekład T. Bieroń, Zysk i S-ka, Poznañ 2012, s. 67-83.
} 
na refleksja autorów ponowoczesnych, która cechuje pesymizm wyrażany również i w katastroficznych terminach charakterystycznych dla opisu poczucia końca bądź wyczerpania. Poza tym nawet u tych $z$ postmodernistów, u których dominuja optymistyczne zapewnienia o wyjątkowych szansach dzisiejszych czasów, daje się wyczuć pesymistyczne tło wywodu - jakby ukryty, głębszy wymiar, przybierający postać nieświadomego niepokoju. Mówiąc jeszcze innymi słowy - popularnym wątkom o niejako karnawalizacji współczesnej kultury towarzyszy przeczucie, że ów karnawał to w istocie bal na Titatanicu. Do myślicieli ponowoczesnych prezentujacych usposobienie pesymistyczne można zaliczyć: Jeana Baudrillarda, Petera Sloterdijka, Slavoja Žižka, Emila Ciorana czy Zygmunta Baumana. Przykładem takiego opisu może być też dzieło A Study of History Arnolda J. Toynbeego z 1947 roku, w którym po raz pierwszy użyto terminu „post-modern” na oznaczeczenie „czasu kłopotów”, tj. fazy, która musi przejść każde społeczeństwo, stające wobec momentu i faktu swego upadku czy końca. Zatem „po-nowożytność” stanowi figurę czasu „upadku”, załamania, rozpadu zwiąanych $z$ powstaniem społeczeństwa masowego. Podobnie Wojciech Zieliński postrzega ponowoczesność w kategoriach „laickiego millenaryzmu czy też katastrofizmu”. Nurt ten wyrasta $z$ „przeświadczenia, że ludzkość znalazła się w czasach ostatecznych, w których doświadczenie kruchości i tymczasowości świata wzięło górę nad tradycyjnym przekonaniem o jego wewnętrznym porządku”35.

Źródła pesymizmu autorów ponowoczesnych tkwią także w Nietzscheańskiej tezie „śmierci Boga”, czyli rozpadzie metafizycznego Absolutu. W wyniku tego nasza kultura uległa zatomizowaniu. Proces ten ma swoje przejawy w przeobrażeniach techno-

\footnotetext{
${ }^{35}$ W. Zieliński: Status etyki $w$ kulturze ponowoczesnej. Analiza propozycji Zygmunta Baumana, Wydawnictwo Adam Marszałek, Torun 2001, s. 42. Z kolei tzw. apokalipsę apokalipsy diagnozuje Wolfgang Welsch w swoich uwagach na temat dekonstrukcji Jacques'a Derridy. Według tego autora Derrida „dekonstruuje kompleksowe wyobrażenie apokalipsa, rozsypuje w pył kilka jego założeń i następstw [...], pokazując obsesję jej innego oblicza. Równocześnie dochodzi do rozpoznania, że apokalipsy nie może być, ponieważ nie ma jej obecności. Apokalipsa jest halucynacją spełnionej obecności". Idem: Nasza postmodernistyczna moderna..., s. 203.
} 
logicznych, a wyraża go też wzrost mobilności społecznej, będący skutkiem rewolucji $\mathrm{w}$ sposobach komunikacji. W konsekwencji człowiek zerwał więzi łączace go $z$ terytorium, wykorzenił się $z$ tradycji i obiektywnych źródeł autorytetu. Ponadto dzięki łączom internetowym świat zaczął być powiązany licznymi współzależnościami, które przebiegaja ponad systemami i w poprzek instytucji państwowych. Tak oto procesy globalizacyjne stały się otwarte i nie daja się wpisywać w linearne koncepcje zmiany społecznej. Tę sytuację opisuja takie pojęcia jak fragmentacja, chaos, masa czy czarna dziura. Opisane procesy mają dalekosiężne konsekwencje, które charakteryzowane sa w terminach katastroficznych i apokaliptycznych.

Kryzysem społeczeństwa, a nawet jego zmierzchem zajmuje się Jean Baudrillard. Teorie Baudrillarda koresponduja $z$ koncepcja końca epoki postępu, zmierzchu konstruktywizmu, którego manifestacją było powstanie nowożytnej socjologii i inżynierii społecznej. Według francuskiego socjologa żyjemy w erze masy - obumarłej, zastygłej, głuchej i niemej, przemienionej w milcząca większość, która nigdy już nie da odpowiedzi na stawiane jej pytania. Jak pisze Baudrillard: „Taka jest masa, uzyskane w stanie próżni skupisko jednostkowych cząstek, odpadów sfery społecznej i medialnych impulsów. Nieprzenikniona mgławica, której wzrastająca gęstość wchłania wszelką energię i wiązki świetlne $z$ otoczenia, by koniec końców zapaść się pod własnym ciężarem. Czarna dziura pochłaniająca społeczność"36.

Bogdan Baran $z$ kolei konstatuje charakterystyczny dla współczesności upadek kultury wysokiej: „nowy kapitalizm niszcząc wszelką autonomię, także autonomię kultury doprowadził do (osobliwej) ruiny, roznosząc tę kulturę na całość życia, ale już tylko w postaci symulaków-reproduktów. [...] powraca więc negatywna ocena postmodernizmu (choć chyba "historycznie koniecznego") jako spadku z wysokiej kultury, tym razem w symulację i populizm"37.

${ }^{36}$ J. Baudrillard: W cieniu milczącej większości..., s. 8.

37 B. Baran: Postmodernizm..., s. 199. 
W kategoriach moralnych współczesny kryzys postrzega zaś Zygmunt Bauman. „Nasze czasy sa czasami silnego poczucia moralnej ambiwalencji. - pisze polski socjolog - Sa to czasy, które pozwalają nam cieszyć się niespotykaną wcześniej wolnością wyboru, ale też rzucają nas w stan rozdzierającej niepewności o nieznanym dotąd natężeniu"38.

Jeżeli chodzi o tęsknotę za przeszłościa, to stosunek do tej idei w myśli konserwatywnej jest sprawa niebudzaca dyskusji. Konserwatyzm cała swoją tożsamość zbudował właśnie na mitologizującym podejściu do minionych czasów, w których wszystko funkcjonowało dzięki oparciu na odwiecznym ładzie i porządku. Można tu jedynie przeciwstawić tę odmianę konserwatyzmu, która pragnęłaby restytuować przeszłość w znaczeniu niemalże dosłownym, takiej odmianie, która jako bardziej realistyczna, nie przeciwstawia się postępowi, o ile ten nie zachodzi zbyt raptownie, a do przeszłości podchodzi z nutą tęsknoty i szacunku. Myśl ponowoczesną również cechuje tęsknota za przeszłością. Źródłem tej skłonności jest, wedle Vattimo, Heideggerowskie nastawienie na wspominanie, przemyśliwanie, przypominanie bycia. Jak pisze Vattimo: „Powrót ten do nikąd nas nie doprowadza, przypomina tylko o byciu jako o tym, z czym już na zawsze się rozstaliśmy"39. To „ślady choroby albo [...] strata, która przeboleliśmy"40 - dodaje Vattimo. Dlatego Richard Rorty porównuje Heideggera $z$ autorem W poszukiwaniu straconego czasu, Marcelem Proustem. Z kolei stojacy na gruncie radykalnego pluralizmu Wolfgang Welsch konstatuje: „żal za utracona całością" ${ }^{41}$. Należy też przypomnieć popularna w środowiskach ponowoczesnych koncepcję „nowego średniowiecza”, artykułowaną zarówno przez Mikołaja Bierdiajewa,

\footnotetext{
${ }^{38}$ Z. Bauman, Etyka ponowoczesna..., s. 34.

${ }^{39}$ G. Vattimo: Koniec nowoczesności..., s. 163.

40 Ibidem, s. 161.

${ }^{41}$ W. Welsch: Nasza postmodernistyczna moderna..., s. 49. Z drugiej jednak strony Welsch pisze: „postmoderna zaczyna się tam, gdzie zostaje przezwyciężony smutek po stracie jedności, gdzie dostrzega się i wykorzystuje pozytywną stronę tej straty: oswobodzenie wielości”. Ibidem, s. 180.
} 
jak i Umberto Eco. Generalnie jednak myśl ponowoczesna traktuje przeszłość jak starą rupieciarnię, w której zawsze można wynajdywać rekwizyty i modele życia przydatne w danym momencie. Dlatego „w ponowoczesności pozostaje jedynie bezkierunkowy przerób wtórny dotychczasowych osiagnięć" ${ }^{\prime 2}$. Podobnie Welsch apeluje, aby nie twierdzić, że „dawne było bezsensowne, zakończone i niebyłe (inexistent); mówiąc krótko, chodzi o to by spróbować grać tym, co dawne"43 bacdź uprawiać „grę resztkami”44, aby użyć terminu Jeana Baudrillarda.

\section{Wobec metafizyki obecności}

W największym stopniu przeciwstawność konserwatyzmu do ponowoczesności jest widoczna w stosunku obu nurtów do zagadnienia tzw. metafizyki obecności. Zarówno u filozofów chrześcijańskich, jak i u ich konserwatywnych kontynuatorów $z$ okresu rewolucji francuskiej widać mocne rysy metafizyki obecności. Obecność tę wyraża idea „rzeczywistości prawdziwej” (przedstawia ją w swoich pracach m.in. Wielomski), która jest porząlkiem uprzednim względem ludzkiego poznania. Ten ład prawdziwy wyraża platońska idea bądź byt prawdziwy, czyli Bóg. $Z$ kolei w ujęciu historycznym ów ład wciela się $\mathrm{w}$ tak silnie afirmowane przez myśl konserwatywna instytucje feudalno-agrarne średniowiecznej Europy wraz $z$ pojęciem ordo. Wychodząc jednak $z$ przeświadczenia, że przeszłości nie da się restytuować, niektórzy z konserwatystów traktuja ja jako swego rodzaju ideę regulatywna, a nie rzeczywisty porządek, do którego należy powrócić. Za metafizyką obecności będzie się wówczas tęsknić jak za porządkiem, który - i tu konserwatyści są zimnymi realistami - przeminą bezpowrotnie. Po-

\footnotetext{
${ }^{42}$ W. Zieliński: Status etyki w kulturze ponowoczesnej..., s. 61.

${ }^{43}$ W. Welsch: Nasza postmodernistyczna moderna..., s. 204.

${ }^{44}$ J. Baudrillard: Gra resztkami, rozm. przepr. S. Mele i M. Timarsh, w: S. Czerniak, A. Szahaj (red.): Postmodernizm a filozofia. Wybór tekstów..., s. 203-228.
} 
stawę konserwatystów będzie cechował dystans do samych siebie i do artykułowanych przez siebie postaw. Koncepcja „rzeczywistości prawdziwej" nie będzie już wyrażana zupełnie na serio, ale $z$ owa szczyptą autoironii, o której pisałem na początku.

Ponowoczesność zaś neguje pojęcie metafizyki obecności, ponieważ - jak to ujmuje Vattimo - „idea fundamentu [...] ulega logicznemu rozpadowi $z$ perspektywy zasadności swoich roszczeń"45. Taka przynajmniej jest powszechnie przyjęta opinia. Teza ta wymaga jednak weryfikacji, którą przeprowadzimy w dalszej części opracowania. Zacznijmy tymczasem od przypomnienia, że myśl ponowoczesna jest zwieńczeniem przeobrażeń, które rozpoczęły się wraz z filozofią oświeceniową. Wyznacznikami tych przeobrażeń była filozofia Kartezjańska i Kantowska. Kartezjusz z próby uczynienia wewnętrznej pewności własnego myślenia (cogito) czynił jeszcze podstawę wiary w Boga. Immanuel Kant natomiast, wraz ze swoja krytyka rozumu, jako pierwszy postawił brzemienne w skutki pytanie: Czy człowiek jest w ogóle w stanie poznać rzeczywistość taką, jaką ona jest, czy też może zajmuje się ciagle modelami myślenia, funkcjonującymi jedynie w jego umyśle? ${ }^{46}$. Bóg przestaje tutaj być realną rzeczywistością, a staje się postulatem ludzkiego rozumu. Niemniej jednak rozum ten, mimo iż abstrakcyjny i transcendentalny, wciąż stanowi źródło nakazów moralnych dla człowieka. Jeszcze dalej na ścieżce emancypacji posuwa się myśl ponowoczesna, choć równocześnie wikła ona człowieka w różne formy nowych zależności ${ }^{47}$.

\footnotetext{
$\overline{45}$ G. Vattimo: Koniec nowoczesności..., s. 158. Jak pisze Vattimo: „Bóg umiera, zabity przez religijność, przez rządze prawdy, która jego wierni zawsze kultywowali, a która teraz doprowadziła ich do odkrycia, że on także był błędem, bez którego można się już teraz obejść”. Ibidem, s. 156.

${ }^{46}$ Ks. I. Bokwa: Nowoczesność i ponowoczesność - wprowadzenie do problematyki, w: ks. K. Góźdź, ks. J. Chyła, ks. S. Kunka (red.): Teologia wobec nurtu ponowoczesności..., s. 67. ${ }^{47}$ Zależności te wedle Michela Maffesolego przybieraja postać ponowoczesnych plemion, które autor nazywa także wspólnotami. Por. M. Maffesoli: Czas plemion. Schyłek indywidualizmu $w$ społeczeństwach ponowoczesnych, przekład M. Bucholc, Wydawnictwo Naukowe PWN, Warszawa 2008. Przywołanie Maffesolego nie jest w tym momencie bezzasadne, gdyż postrzeganie przez tego autora ponowoczesności jako schyłku indywidualizmu kłóci się $z$ dość powszechnie przyjmowaną (a propagowana zwłaszcza przez Lyotarda i Welscha)
} 
Punktem wyjścia do określenia stosunku myśli ponowoczesnej do metafizyki obecności jest zakwestionowanie klasycznej definicji prawdy jako zgodności sądów o rzeczywistości $z$ samą rzeczywistościa, czyli zgodności pojęcia $z$ przedmiotem, przedstawienia $z$ przedstawianym. Myśliciele ponowocześni kieruja się, jak pisał Rorty, „metaforami tworzenia, miast odkrywania, różniczkowania i nowatorstwa, miast przybliżania się do tego, co zawsze obecne"48. W ujęciu tym nie chodzi o relatywizm poznawczy, który zarzucaja autorom ponowoczesnym (nie zawsze słusznie jak dowodzi Bauman) ich oponenci. Znacznie ciekawsza jest ponowoczesna koncepcja rozdzielenia języka od jego desygnatu (obiektywnej rzeczywistości), zastapienia paradygmatu referencyjności paradygmatem wewnątrzlingwistycznym (mówi się o słowach, pisze się o tekstach, intertekstualność) ${ }^{49}$. To nauka o języku, który nie jest już zakotwiczony w świecie. Chodzi o to, że słowa, tekst, mowa, sądy nie referuja już rzeczywistości. I to nie referuja jej ani w sposób prawdziwy (jak to czyniła filozofa klasyczna), ani w sposób fałszywy (jak to zarzucali filozofii oświeceniowej konserwatyści), w ogóle zanika bowiem proces referencji. Słowa, tekst, mowa odnosza się same do siebie ${ }^{50}$. Filozofia, według słów Jacques’a Derridy jest wyłącznie „rodzajem pisma” ${ }^{1}$. „Czytanie i pisanie, pisanie/czytanie

\footnotetext{
teza, że ponowoczesność należy postrzegać w kategoriach pluralizmu i dyferencji. Podobne poglądy prezentuje Baudrillard. Jak pisze o nim Welsch: „Niepohamowany wzrost wielości powoduje zarazem zobojętnienie na wprowadzane przez nia możliwości, które neutralizuja się wzajemnie i współbrzmią w czystym upojeniu niezróżnicowaniem”. Zob. W. Welsch: Nasza postmodernistyczna moderna..., s. 206.

${ }^{48}$ R. Rorty: Przygodność, ironia, solidarność, przekład J. Popowski, Wydawnictwo Spacja, Warszawa 1996, s. 112.

49 J.-F. Lyotard: Postmodernizm dla dzieci. Korespondencja 1982-1985, przekład J. Migasiński, Fundacja Aletheia, Warszawa 1998, s. 8.

${ }^{50}$ Jak pisze Bogdan Banasiak w książce o dekonstrukcji Jacques'a Derridy: „Odkrycie poprzedzającego obecność nieobecności, [...] czegoś (obecności) co sytuowałoby się poza tekstem i go poprzedzało (to samo nie jest bowiem ze soba tożsame, zatem źródło rozspajane jest przez różnicę), ujawnia nieredukowalność pisma [...]. To signifiant pozbawione swego signifie, znaczace pozbawione znaczonego, jednoelementowy znak (ślad, gram), który nie jest konstytuowany przez sens, lecz okazuje się tylko znamieniem samego siebie, tylko do siebie odsyła i siebie oznacza". Zob. B. Banasiak: Filozofia "końca filozofii». Dekonstrukcja Jacquesa Derridy, Wydawnictwo Spacja, Warszawa 1995, s. 101-102.

${ }^{51}$ Jak pisze Christopher Norris: „Derrida doprowadził, [...] do uderzającego odwrócenia odwiecznego przesądu, który wynosi filozofię ponad retorykę, czy też rozum właściwy ponad
} 
to gra, która poza kontynuacja gry dla niej samej nie ma żadnego innego celu"52 - pisze komentator dzieł Derridy.

Zgodnie $z$ tym samym rozumowaniem kultura ponowoczesna zapowiada upadek nowoczesnego rozróżnienia na rzeczywistość i symulacje. Na upadek ten zwraca uwage zwłaszcza Jean Baudrillard, według którego „nie istnieje czekająca na odkrycie głębia bytu, a autosemantyczność nie jest wyłącznie cechą języka, lecz również w coraz większym stopniu, cechą samej kultury ponowoczesnego świata"53. Baudrillard swoje koncepcje o niemożliwości odróżnienia tego, co pozorne od tego, co realne wykorzystuje do analizy sposobu działania mediów, reklamy, telekomunikacji i Internetu, w czym zbliża się do rozważań Marshala McLuhana.

W podobnym duchu wypowiada się Gianni Vattimo, zauważając upadek rozróżnienia na baśń i rzeczywistość: „Kiedy już został odkryty baśniowy charakter prawdziwego świata, niechaj i baśni przywrócona zostanie niegdysiejsza metafizyczna godność (chwała) prawdziwego świata"54. W ten sposób Vattimo wyraża niewypowiedziana tęsknotę za utracona metafizyką obecności. Innymi słowy - Vattimo za Nietzschem mówi, że baśń przestaje być baśnią, bowiem nie ma już żadnej prawdy, która odsłaniałaby jej iluzję. Używając określenia stosowanego zarówno przez Zygmunta Baumana, jak i Michela Maffesolego, naturę tego procesu oddaje "ponowne zaczarowanie świata" 55 .

Stosunek myśli ponowoczesnej do metafizyki obecności można też wyrazić w innych terminach. Zacznijmy od twierdzenia, ỉ

\footnotetext{
maskujące się sztuki językowe”. Idem: Dekonstrukcja, postmodernizm a filozofia. Habermasa krytyka Derridy, w: B. Banasiak (red.): Derridiana, Inter esse, Kraków 1994, s. 107.

${ }^{52}$ M. Świerkowski: Derrida jako postmodernistyczny pismak czyli doskonałość niedoskonałości, w: B. Banasiak (red.): Derridiana..., s. 141. Jak pisze ten autor: „Derrida nie mówi już o recepcji dzieła, lecz o pracy na tekście, która nie odkrywa prawd czy znaczeń, lecz produkuje, rozplenia sensy". Ibidem.

${ }^{53}$ B. Smart: Postmodernizm, przekład M. Wasilewski, Wydawnictwo Zysk i S-ka, Poznań 1998, s. 160.

${ }^{54}$ G. Vattimo: Koniec nowoczesności..., s. 21.

${ }^{55}$ Jak pisze Maffesoli: „Jeśli więc można mówić o ponownym zaczarowaniu świata, to trzeba powiedzieć, że zachodzi ono samo z siebie". M. Maffesoli: Czas plemion..., s. 75.
} 
w myśli ponowoczesnej panuje niemały galimatias: przemieszany jest tu opis $z$ wyjaśnieniem, faktyczny stan rzeczy $z$ norma, a diagnoza $z$ ocena ${ }^{56}$. Interesuje nas tutaj ta odmiana myśli ponowoczesnej, która rezygnując $z$ chęci tworzenia jakiejś ogólnej teorii, skupia się raczej na byciu odbiciem, śladem wymienianego powyżej „faktycznego stanu rzeczy”. Zwraca na nia uwage Welsch, kiedy pisze, iż w przeciwieństwie do nowoczesności, która miała charakter ezoteryczny, ponowoczesność ma charakter egzoteryczny, tzn. jest dzisiaj urzeczywistniana $\mathrm{w}$ życiu codziennym ${ }^{57}$. W tym samym duchu pisze Bartosz Kuźniarz: „[...] postmodernizm zdążył wszak opuścić mury akademii i stać się elementem naszej codzienności, przeszedł drogę od składni awangardowego wiersza do kształtu obudowy kupowanych przez nas telewizorów, od postmodernizmu do ponowoczesności" ${ }^{58}$.

$\mathrm{Na}$ wage tego nurtu i jego miejsce w szeroko rozumianej refleksji ponowoczesnej zwraca uwage także Zieliński, gdy pisze: „brak epistemologicznego i aksjologicznego gruntu refleksji etycznej proklamowany jest przez myśl postmodernistyczna, ale, co ważniejsze, wynika on w jakimś sensie także $z$ realiów współczesnego świata. $\mathrm{O}$ ile nic nie zmusza nas do przyjmowania postmodernistycznych idei - należących wszak tylko do jednego $z$ kilku funkcjonujących dziś wzorów kultury intelektualnej - o tyle konieczne jest uwzględnienie tych ponowoczesnych realiów"59.

Autor dotyka tutaj sedna rzeczy. Nic nie zmusza nas bowiem do przyjmowania „postmodernistycznych idei”. Wręcz przeciwnie, możemy za własne uznać idee konserwatywne i je proklamować, ale to nie rozwiąże problemu, jest bowiem jeszcze coś takiego jak „ponowoczesne realia”, w otoczeniu których musimy wieść swój żywot. Realiów tych nie musi projektować żadna elita naukowa zamknięta na uniwersyteckich katedrach, powstają one same $z$ sie-

\footnotetext{
${ }^{56}$ W. Zieliński: Status etyki $w$ kulturze ponowoczesnej..., s. 42.

${ }^{57}$ W. Welsch: Nasza postmodernistyczna moderna..., s. 116-117

${ }^{58}$ B. Kuźniarz: Goodbye Mr. Postmodernizm. Teorie społeczne myślicieli później lewicy, Wydawnictwo Naukowe Uniwersytetu Mikołaja Kopernika, Toruń 2011, s. 14.

${ }^{59}$ W. Zieliński: Status etyki w kulturze ponowoczesnej..., s. 97.
} 
bie, oddolnie, moca inercji. Odpowiedzialne sa za nie dokonujace się przeobrażenia telekomunikacyjne, związane $z$ eksplozją przemian informacyjnych generowanych przez massmedia. I właśnie w ukazywaniu tych realiów, czyli faktycznego stanu rzeczy wraz $z$ ich powikłaniem i wewnętrzną złożonościa, zasadza się, według mnie, główna zasługa myśli ponowoczesnej.

Zgodnie $z$ takim ujęciem charakterystyczna dla ponowoczesności teza o „śmierci Boga” nie będzie mieć charakteru sądu wartościującego, bo takich sądów w ogóle myśl współczesna nie artykułuje. Raczej chodzi w niej o ukazanie procesu oddolnego rozproszenia. Głównie dzięki przemianom technologicznym społeczeństwo uległo procesom atomizacji, interioryzacji i indywidualizacji, tj. rozpadło się na indywidualne sady. Ponowoczesność będzie tu zatem traktowana nie jako kolejny światopogląd wymierzony $\mathrm{w}$ burzenie ładu tradycyjnego (jak chce ją widzieć Wildstein i myśl chrześcijańska), ale jako ponura diagnoza dotyczaca opłakanego stanu naszej kultury, którą rządzi teza o „śmierci Boga” (końcu „metafizyki obecności”). Jak wykazałem w drugiej części artykułu, $\mathrm{w}$ tej pesymistycznej diagnozie myśliciele ponowocześni wykazuja zbieżność $z$ myślicielami konserwatywnymi.

\section{Zakończenie}

$\mathrm{Na}$ podstawie powyższych analiz można stwierdzić, iż mimo istotnych różnic między myślą konserwatywną a ponowoczesna istnieja też pewne podobieństwa. Należy do nich wspólna ocena rozumu instrumentalnego i idei postępu. Oba nurty światopoglądowe łączy także podobnie pesymistyczna diagnoza stanu współczesnej kultury, która ulega tendencjom rozkładowym, oraz tęsknota za przeszłością. Największa różnica dotyczy stosunku do metafizyki obecności oraz idei prawdy w świecie. Dobitnie prezentuje się w tym kontekście przeciwstawność idei „rzeczywistości prawdziwej” diagnozowanej przez Wielomskiego z koncepcja, 
że „prawdziwy świat Platona to zwykła bajka" ${ }^{60}$. Nie negując wagi tej różnicy, należy raz jeszcze przypomnieć, że odejście od prawdy nie ma dla autorów ponowoczesnych charakteru zdecydowanego sac $^{61}$, raczej chodzi w niej o pokazanie dominujacych w społeczeństwie tendencji myślenia, a nie o afirmację jakiejś prawdy. Poza tym myśl ponowoczesną cechuje podobna do myśli konserwatywnej metafizyczna tęsknota, doświadczenie straty, z czym nie możemy się do końca pogodzić. Generalnie należy skłonić się ku tezie, że myśl ponowoczesna - mimo jej lewicowych korzeni jest bardzo ważna $z$ poznawczego punktu widzenia, także dla konserwatystów, gdyż postmoderniści we właściwy sposób diagnozuja skomplikowany stan współczesnej kultury. Analizy tego stanu wykazuja zbieżność $z$ ponurymi diagnozami konserwatystów, które były już przytaczane. Dlatego nie ma nic bardziej błędnego niż zamknięcie się na ponowoczesność w wieży z kości słoniowej, groźne jej egzorcyzmowanie i skupianie się wyłącznie na studiach filozofów klasycznych, aby sporządzać, jak to mówią - nie bez ironii - postmoderniści, kolejne „przypisy do Platona”. Według piszacego te słowa, trzeba wejść w ponowoczesność, głęboko się w niej zanurzyć i starać się odpowiadać na artykułowane przez nią pytania. Każdy król musi mieć swojego błazna, jak pisaliśmy w motto do artykułu, dlatego też obok filozofii królewskiej (platońsko-chrześcijańskiej) musi istnieć też ta błazeńska (ponowoczes-

\footnotetext{
${ }^{60}$ R. Rorty: Przygodność, ironia, solidarność..., s. 51. Teza ta odwołuje się do tytułu rozdziału F. Nietzschego pt: Jak świat prawdziwy stał się w końcu bajka z dzieła Zmierzch bożyszcz. por. F. Nietsche: Zmierzch bożyszcz czyli Jak filozofuje się młotem, przekład P. Pieniążek, Wydawnictwo „Zielona Sowa”, Kraków 2004, s. 25-27. Zgodnie z opinią Heideggera w tym twierdzeniu Nietzsche dokonuje odwrócenia tezy Platona, tak by rzeczywiste było to, co Platon traktował jako zjawisko.

${ }^{61}$ Jak pisze Richard Rorty: „Powiedzenie, iż winniśmy porzucić ideę prawdy, która czeka na zewnątrz, abyśmy mogli ją odkryć, nie oznacza, że odkryliśmy, iż na zewnattrz prawdy nie ma. Równa się to stwierdzeniu, że ze względu na cele, o które nam chodzi, najlepiej będzie, gdy prawde przestaniemy uważać za głęboka materię, za przedmiot filozoficznego zainteresowania, a prawdziwy za termin wart analizy”. R. Rorty: Przygodność, ironia, solidarność..., s. 25. W innym zaś miejscu Rorty pisze o Derridzie: „Można by go porównać do ateisty, który nie mówi: "nie ma Boga", ale raczej: "cała ta mowa o naszym stosunku do Boga przeszkadza nam"”. Idem: Filozofia jako rodzaj pisarstwa. Esej o Derridzie, w: S. Czerniak, A. Szahaj (red.): Postmodernizm a filozofia. Wybór tekstów..., s. 93.
} 
na), która w krzywym zwierciadle pokaże samą siebie i otaczajacy nas świat, tym samym wyposażając nas w pokłady dystansu do siebie samych i do naszego położenia w świecie.

Do tego celu posłuży wysoko ceniona zarówno przez rewolucyjnych konserwatystów, jak i myślicieli ponowoczesnych filozofia Nietzschego i Heideggera, których myśl może być traktowana jak swoista „tarcza obrotowa”, tj. można ich poglądy wykorzystywać także w uzasadnianiu tez drogich konserwatystom. Jak przypuszcza w tym właśnie duchu i będacy pod ich wpływem Scott Lash w analizach dotyczacych modernizacji refleksyjnej: „[...] być może rolę tę spełni hermeneutyka odzyskania, która w przeciwieństwie do koncepcji mistrzów (i współczesnych czeladników) podejrzeń - nie będzie bez końca burzyć fundamentów, ale podejmie próbę odsłonięcia ontologicznych podstaw wspólnotowego bycia-w-świecie"62. Innymi słowy - może chodziłoby o stworzenie jakiejś odmiany ponowoczesnego konserwatyzmu bąź postkonserwatyzmu, kierunku, który zgodnie $z$ przytaczana powyżej hermeneutyka odzyskania i w duchu ironii będzie wciąż na nowo podejmować inicjatywę rekonstrukcji świata, jego posklejania $z$ porozrzucanych odpadów $\mathrm{i}$ to pomimo smutnego skądinąd przeświadczenia, iż inicjatywa ta w szerszej perspektywie skazana jest na niepowodzenie.

${ }^{62}$ U. Beck, A. Giddens, S. Lash: Modernizacja refleksyjna. Polityka, tradycja i estetyka w porzadku społecznym nowoczesności, przekład J. Konieczny, Wydawnictwo Naukowe PWN, Warszawa 2009, s. 192-193. 